\title{
THE FECUNDITY OF THE HERRING OF THE SOUTHERN NORTH SEA
}

\author{
By C. F. Hickling, M.A. \\ Fisheries Laboratory, Lowestoft
}

(Text-figs. I-4)

During the great East Anglian herring fishery of the autumn of I933, material was collected for an investigation into the number of eggs produced by the herring. Hodgson (I925) has shown that most of the females of these herrings are in the penultimate stage of maturity (the Stage V of Hjort), that is, the contained eggs are large and yolky, but not yet glass-clear and ready to be spawned.

Hickling \& Rutenberg (I936) have shown that, in the herring, the eggs destined to be spawned in the current season are ripened simultaneously, for there is, in an ovary in an advanced stage of ripeness, a very sharp separation in point of size between the active yolky eggs and the small yolkless ones. Farran (I938) likewise found that all the ripening eggs in a herring ovary are of approximately equal size, and that the number of eggs destined to ripen is fixed from the time that the storage of yolk has begun. In the herring, therefore, the large yolky eggs are the whole of the season's crop of eggs, and a count of them will give the absolute fecundity of the fish.

It is a simple matter to separate these yolky eggs from the ovary. The method used was modified from that of Raitt (I933). The ovaries, preserved and hardened in formalin, were cut into pieces, and shaken vigorously with water in a stoppered jar. The yolky eggs dropped out of their follicles and fell to the bottom of the jar. By removing the connective tissue of the ovary a complete separation of the yolky eggs was made without difficulty.

The eggs were counted by the method used by Nuttall (I9I3) in counting the eggs of ticks. On an ordinary sheet of glass three strips of glass are cemented in the form of a right-angled $U$, between the arms of which a fourth strip of glass slides readily backwards and forwards whilst closely applied to the arms of the $U$ like a piston in a cylinder. Within the rectangle so formed the eggs to be counted are spread so as to form a uniform layer one egg deep. The product of the number of eggs lying against two adjacent sides of the rectangle is the number of eggs in the whole rectangle, and this first estimate may be checked by a count of the number of eggs against the remaining two sides of the rectangle.

Besides these observations on the fecundity of the herring, observations on the weight of the fish and of its gonads were made on some 475 herrings of known sex, length, and age. 


\section{The Fecundity of the HerRing}

In Table I are given the mean number of eggs produced by herrings at each centimetre of length, and at each age.

Table I. The Fecundity of the Herring

\begin{tabular}{|c|c|c|c|}
\hline $\begin{array}{l}\text { Mid-length } \\
\mathrm{cm} .\end{array}$ & Frequency & $\begin{array}{c}\text { Mean no. } \\
\text { of eggs }\end{array}$ & $\begin{array}{c}\text { Calculated n } \\
\text { of eggs }\end{array}$ \\
\hline \multicolumn{4}{|c|}{ A. By length } \\
\hline $2 \mathrm{I} \cdot 5$ & 2 & I 2,570 & I 2,223 \\
\hline $22 \cdot 5$ & 3 & 12,250 & 14,315 \\
\hline $23 \cdot 5$ & 17 & 17,225 & 16,645 \\
\hline $24 \cdot 5$ & 30 & $2 \mathrm{I}, 6 \mathrm{II}$ & I 9,230 \\
\hline $25 \cdot 5$ & 30 & 22,322 & 22,074 \\
\hline $26 \cdot 5$ & 29 & 24,904 & 25,223 \\
\hline $27 \cdot 5$ & 17 & 28,475 & 28,679 \\
\hline $28 \cdot 5$ & 7 & 33,223 & 32,434 \\
\hline $29 \cdot 5$ & I & 34,450 & 36,599 \\
\hline \multicolumn{4}{|c|}{ B. By age } \\
\hline 3 & 2 & I2,570 & I 4,620 \\
\hline 4 & 39 & $18,8 \mathrm{I} 4$ & 17,679 \\
\hline 5 & 21 & 23,208 & 20,482 \\
\hline 6 & 40 & 23,200 & 23,102 \\
\hline 7 & I6 & 27,102 & 25,580 \\
\hline 8 & 5 & 24,690 & 27,931 \\
\hline 9 & 8 & 30,924 & 30,189 \\
\hline IO & 5 & 33,464 & 34,458 \\
\hline
\end{tabular}

Table I A shows that the number of eggs produced increased rapidly with increase of length. By the method of least squares it can be calculated that the formula which best expresses the relation between length and fecundity is

$$
F=0.2954 L^{3.465} \text {. }
$$

Fecundity, therefore, increases with length at a rate substantially greater than the third power of length. Farran (1938) found that in the Irish herrings the rate of increase was of the order of the 4.5 power of length.

The data given in the table above are shown in Fig. I, where the line shows the calculated mean fecundity at each centimetre. They are in excellent agreement with the data published by Fulton (I89I). The herrings he investigated were also winter-spawning fish, and mostly greater than II in. in length. If the number of eggs found in the fourteen herrings greater than II in. in length dealt with by Fulton is compared with that found among the twentyfive herrings greater than $27 \mathrm{~cm}$. in length in the present work, it is found that the mean number of eggs produced is 32,470 according to Fulton, and 30,043 according to the present work. But on applying the statistical test of the Significance of the Difference between Means to the two arrays, it is found that there is no significant difference between them. The calculated value of " $t$ " is I.0447I, corresponding to a value of $P$ of 0.3 (Fisher, 1938). Therefore a difference between the means as great as, or greater than, that found, would 
occur by chance in homogeneous material in three trials out of ten. Fulton's results, and those here presented, are therefore in agreement.

Very different results were obtained by Mitchell (I9I3). She found values for the fecundity of the herring nearly three times as great as those found by Fulton. But Fulton noted that summer herring were said to be more fecund than winter herring, and the specimens examined by Mitchell were summer spawners.

Farran (1938) found that, in fish of the same length, the spring spawners produced about half as many eggs as the autumn spawners, though the eggs were $25 \%$ larger. It is interesting to note that the fecundity of the winter spawners dealt with by Fulton and in the present paper lies between those for


Fig. I. Rate of increase in the fecundity of the herring with length and age.

the autumn and spring spawners, as shown by Farran's figures. It may be that the fecundity of the herring is adapted in some way to the seasons, for the order of fecundity seems to be as follows: least fecund in spring spawners, more fecund in winter spawners, still more fecund in autumn spawners, and most fecund in summer spawners. One is tempted to relate this with the plankton cycle; and in any case the fecundity should be, as Farran shows, a valuable means of distinguishing between herrings of different "seasonal races".

The relation between age and fecundity is shown in Table I B. The formula which best expresses the relation between age and fecundity is

$$
F=7080 \mathrm{Age}^{0.66} \text {. }
$$

The calculated regression is shown in Fig. I as a curve, and it would indicate a gradual falling off in the rate of increase of fecundity with increase of age. Farran also found indications of a decline in fecundity among the larger herrings in his samples. 


\section{The Weight OF THE GoNadS}

In Table II are given the average weights of the gonads of the herring at each centimetre of length, and at each age.

Table II. Mean Weight of the Gonads of the Herring

A. By length

\begin{tabular}{|c|c|c|c|c|c|c|}
\hline \multirow{2}{*}{$\begin{array}{l}\text { Mid-length } \\
\mathrm{cm} \text {. }\end{array}$} & \multicolumn{2}{|c|}{ Frequency } & \multicolumn{2}{|c|}{$\begin{array}{l}\text { Mean wt. } \\
\text { (g.) }\end{array}$} & \multicolumn{2}{|c|}{$\begin{array}{l}\text { Calculated } \\
\text { mean wt. (g.) }\end{array}$} \\
\hline & $0^{t}$ & 우 & $\sigma^{*}$ & 우 & $\hat{\sigma}$ & 우 \\
\hline $\begin{array}{l}21 \cdot 5 \\
22 \cdot 5 \\
23 \cdot 5 \\
24 \cdot 5 \\
25 \cdot 5 \\
26 \cdot 5 \\
27 \cdot 5 \\
28 \cdot 5\end{array}$ & $\begin{array}{r}4 \\
21 \\
50 \\
88 \\
68 \\
23 \\
3\end{array}$ & $\begin{array}{r}\text { I } \\
\text { I } \\
\text { II } \\
50 \\
77 \\
61 \\
16 \\
\text { I }\end{array}$ & $\begin{array}{l}\text { I2.0 } \\
\text { I5.6 } \\
19 \cdot 5 \\
24 \cdot 0 \\
26 \cdot 7 \\
27 \cdot 3 \\
35.0\end{array}$ & $\begin{array}{l}13.0 \\
17.4 \\
18.5 \\
22.0 \\
27.9 \\
29.2 \\
38.0\end{array}$ & $\begin{array}{l}12.9 \\
15.5 \\
18.5 \\
22.0 \\
25 \cdot 8 \\
30 \cdot 2 \\
35 \cdot 2\end{array}$ & $\begin{array}{l}12 \cdot 8 \\
16 \cdot 6 \\
19 \cdot 6 \\
23 \cdot 0 \\
26 \cdot 8 \\
31 \cdot 1 \\
35 \cdot 8\end{array}$ \\
\hline \multicolumn{7}{|c|}{ B. By age } \\
\hline $\begin{array}{r}3 \\
4 \\
5 \\
6 \\
7 \\
8 \\
9 \\
\text { II }\end{array}$ & $\begin{array}{r}18 \\
32 \\
\text { I06 } \\
\text { I8 } \\
34 \\
43 \\
5 \\
\mathrm{I}\end{array}$ & $\begin{array}{r}9 \\
37 \\
98 \\
\text { II } \\
15 \\
46 \\
2\end{array}$ & $\begin{array}{l}15 \cdot 6 \\
19 \cdot 3 \\
22 \cdot 2 \\
26 \cdot 1 \\
25 \cdot 3 \\
28 \cdot 8 \\
31 \cdot 2 \\
42 \cdot 0\end{array}$ & $\begin{array}{l}\mathrm{II} \cdot 9 \\
\mathrm{I} 9 \cdot 2 \\
2 \mathrm{I} \cdot 6 \\
25 \cdot 5 \\
27 \cdot 3 \\
29 \cdot \mathrm{I} \\
37 \cdot 0\end{array}$ & $\begin{array}{l}15.5 \\
18.9 \\
22.0 \\
24.9 \\
27.7 \\
30.3 \\
32.9 \\
37.7\end{array}$ & $\begin{array}{l}13 \cdot 2 \\
17 \cdot 1 \\
20 \cdot 9 \\
24 \cdot 6 \\
28 \cdot 3 \\
31 \cdot 9 \\
35 \cdot 5\end{array}$ \\
\hline
\end{tabular}

The data are shown graphically in Fig. 2. It would seem that the ovary is heavier than the testis at any given length, but that, while the mean weight of the testis is greater than that of the ovary among the younger fish (Table II B) among the older fish the reverse is found.

The formulae which best express the relation between the length of the fish and the weight of its gonad are

$$
\text { for the males } W=0.000024 \mathrm{II} L^{4.2371} \text {, }
$$

and $\quad$ for the females. $W=0.0000594 L^{3.973}$.

The weight of the testis therefore increases with length at a slightly greater rate than the ovary, but both increase at a rate about proportional to the fourth power of the length. Farran (1938) found that the ovary of the herrings he investigated increased with length at a somewhat greater rate, namely, as the 4.5 power of length.

Comparing the increase in weight of the ovaries, with increase of length, with the increase in the number of eggs produced, it will be noted that the former increases at a slightly greater rate, namely, as $L^{3.97}$ is to $L^{3.47}$. The discrepancy is due to the simultaneous increase in weight of the permanent tissue of the ovary. Nevertheless, since the production of eggs is the dominant 
function of the ovary, a close correlation should be expected between the mean weight of the ovary and the mean number of eggs produced. This is so; the correlation coefficient is $0.9692(P<0.01)$, and one gramme of ovary is equivalent to 965 eggs.
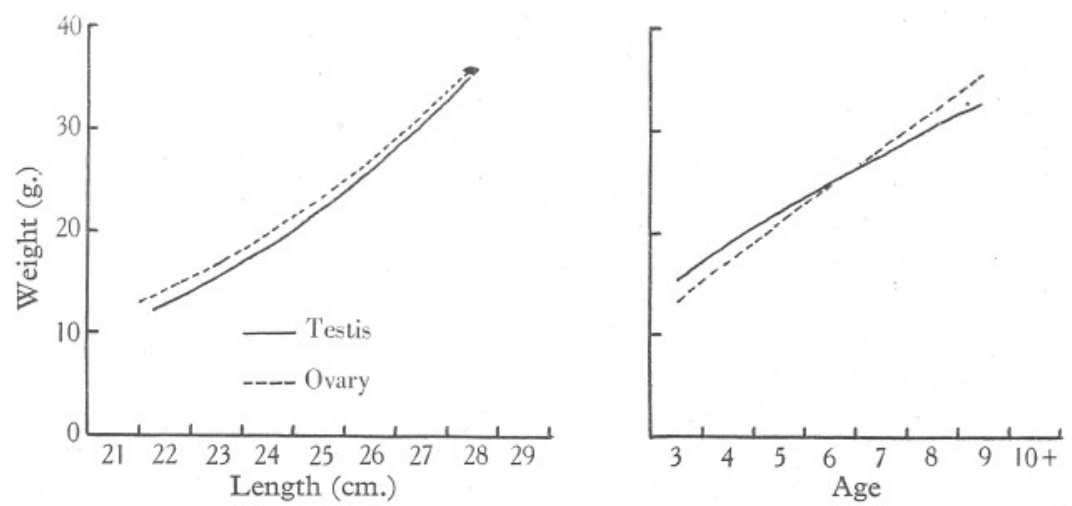

Fig. 2. Rate of increase in the weight of the gonads of the herring with length and age.

In Fig. 2 is also shown the relation between the age of the fish and the mean weight of the gonads. The ovary increases in weight, with increase of age, at a faster rate than the testis. This may be seen in the formulae below, which express the relation between the age of the fish and the mean weight of the gonads.

For the males $W=7.307 \mathrm{Age}^{0.684}$.

For the females $W=4.873 \mathrm{Age}^{0.904}$.

Comparing the rate of increase in the mean weight of the ovary, with age, with that of the mean number of eggs produced, it will be seen that the former increases at a substantially greater rate than the latter, namely, as $\mathrm{Age}^{0.90}$ is to $\mathrm{Age}^{0.66}$. But the production of a crop of eggs is an annual event, and it is attended by enormous changes in the volume of the ovary. It would therefore be expected that the permanent tissue of the ovary would show a considerable increase of thickness as a result of these successive expansions and contractions, and that the weight of the permanent tissue would increase more rapidly with age than with length, and more rapidly than the number of eggs produced.

\section{The WeIght OF THE Fish}

In Table III are given the mean weights of the gutted herring of both sexes at each centimetre of length, and of the gutted herring together with their gonads.

The weight of the gutted fish alone increases, with length, according to the following formula,

$$
W=0 \cdot 1212 L^{2 \cdot 132} \text {. }
$$

That is, it increases at a rate nearer the square than the cube of the length. 


\begin{tabular}{|c|c|c|c|}
\hline \multirow{3}{*}{$\begin{array}{l}\text { Mid-length } \\
\mathrm{cm} .\end{array}$} & \multicolumn{2}{|c|}{ TABLE III } & \multirow[b]{2}{*}{$\begin{array}{l}\text { Calculated } \\
\text { mean weight } \\
\text { g. }\end{array}$} \\
\hline & Frequency & $\begin{array}{l}\text { Mean weight } \\
\text { g. }\end{array}$ & \\
\hline & \multicolumn{3}{|c|}{ A. Mean weight of the gutted fish } \\
\hline $2 \mathrm{I} \cdot 5$ & I & 80 & 84 \\
\hline $22 \cdot 5$ & 5 & 98 & 93 \\
\hline 23.5 & 32 & 102 & 102 \\
\hline 24.5 & 100 & III & III \\
\hline 25.5 & 165 & I2I & I2I \\
\hline $26 \cdot 5$ & 129 & 132 & I3I \\
\hline 27.5 & 39 & 140 & $\mathrm{I} 42$ \\
\hline 28.5 & 4 & 153 & 153 \\
\hline
\end{tabular}

B. Mean weight of the gutted fish plus the gonads

\begin{tabular}{|c|c|c|c|}
\hline $2 \mathrm{I} \cdot 5$ & I & 94 & 96 \\
\hline 22.5 & 5 & IIO & 107 \\
\hline 23.5 & 32 & I I 8 & II 8 \\
\hline 24.5 & IOO & I30 & I3I \\
\hline 25.5 & 165 & I44 & I44 \\
\hline 26.5 & 129 & I 59 & I57 \\
\hline $27 \cdot 5$ & 39 & I68 & I 72 \\
\hline & 4 & 189 & 187 \\
\hline
\end{tabular}

Other series of weights of herrings are available in the literature, but these are in every case the weights of the entire fish. To make the results here given comparable with these other series, it would be necessary to add to the weight of the gutted fish the weight of the gonad and gut. But, in the East Anglian herring shoals, the fish are not feeding, and the gut is a small organ weighing only a small percentage of the weight of the fish. It is proposed to neglect the weight of the gut, and to calculate only the relation between the length of the fish and the combined weights of the fish and its gonad. These data are given in Table III B, and from them the best-fitting equation of length and weight has been calculated. It is

$$
W=0.06618 L^{2.372} \text {. }
$$

Bjerkan (1917) gives data as to the weights of herrings taken at North Shields. From these it would appear that the best-fitting equation is

$$
W=0.0421 L^{2.520} \text {. }
$$

These herrings were mainly in Stage V of maturity, thus in much the same stage as those of East Anglia.

Orton (I9I6) gives a very complete series of data as to the length and weight (among a great number of other observations) of herrings taken in some hauls in the English Channel in December and January I9I4-I5. From his Table 3 the weights of some 20 fish at each half-centimetre of length were taken, and the mean weight at each half-centimetre calculated. The formula which best expresses the relation between length and weight is as follows

$$
W=0.005838 L^{3.0875} \text {. }
$$

These fish were taken in December, and had an average maturity, on Hjort's scale, of $4 \cdot 5$. In Orton's Table 4 are given the corresponding data for 
herrings taken in a haul in January. These herrings were in an average state of maturity of $5 \cdot 2$, and had a different relation between length and weight. This relation may be expressed by the formula

$$
W=0.04108 L^{2.5006} .
$$

Keys (1928) and Fraser (as quoted by Marshall et al. 1939) also used Orton's data to calculate the relation between weight and length in the herring. Their formulae are

$$
\begin{aligned}
& \text { Keys, } W=0.00268 L^{3.50} . \\
& \text { Fraser, } W=0.00000337 L^{3.149} .
\end{aligned}
$$

Neither formula fits the data extracted for the present paper, but, no doubt, much would depend on which of Orton's tables were used, and how the data were taken from them.

But the present writer's calculations show that, at least in herrings in an advanced state of maturity, the weight of the entire fish increases, with length, at a rate much less than the cube of the length, and therefore the fish alone, without the gonads and gut, must increase, with length, at an even slower rate, nearer the square than the cube of the length.

Among the small and immature herrings a different rate is found. Marshall et al. (I939) give data as to the weight of young herrings taken in the Firth of Clyde. From the data of fish caught in November and February, the relation between the wet weight of the fish, and length, is

$$
W=0.004224 L^{3.120} \text {. }
$$

In these immature herrings, of a length from 9.8 to $14.9 \mathrm{~cm}$., the weight increased with length at a rate greater than the cube of the length.

Bjerkan (I9I7) gives a series of weights of "small fat herrings" from northern Norway, of a length from 16.0 to $24.5 \mathrm{~cm}$. The relation between length and weight in these herrings, which were still immature, or, in the case of the largest fish, about to mature for the first time, is as follows,

$$
W=0.006247 L^{3.0009} \text {. }
$$

As a third comparison between the length-weight relation in young and small, and old and large herrings, the data published by Lea (I9I0) may be used. His Collection 6 gives the weight and length of a sample of herrings caught with the seine in northern Norway. The fish were all either immature, or, in the case of the largest fish, about to mature for the first time; their range in length was from 15.9 to $27.7 \mathrm{~cm}$. The formula which best expresses the relation between length and weight in these herrings is

$$
W=0.001772 L^{3.422} \text {. }
$$

Thus the weight increased at a rate much greater than as the cube of the length. On the other hand, a sample of small herrings, of 13 to $19 \mathrm{~cm}$., caught in the southern North Sea in August 1939, showed the following relation between length and the weight of the gutted fish

$$
W=0.0270 L^{2.561} \text {. }
$$


This rate of increase of weight is less than as the cube of the length, but is nevertheless substantially greater than the rate shown by the gutted mature herring of the southern North Sea which, as has been shown above, is as the 2.I power of length.

In Table IV below, the herring material from the southern North Sea studied by me has been drawn up so as to show for each sex at each centimetre length and also at each age the mean weight of the gutted fish.

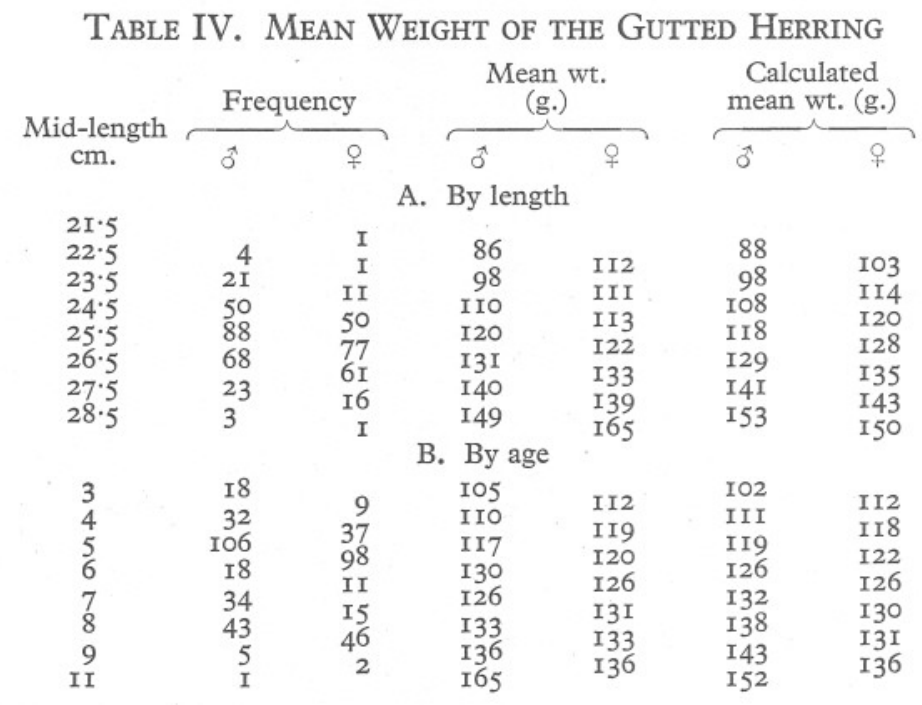

It would appear that the female has a greater mean weight than the male at lengths below $27 \mathrm{~cm}$. but, as the differences are small, it is advisable to apply the test of the Significance of the Difference between Means to the data. There are too few observations at $2 \mathrm{I} \mathrm{cm}$. and $22 \mathrm{~cm}$. to apply this test, but the mean weight of the female is much greater than that of the male among these small fish. Below are given the values for " $t$ ", and the corresponding values of $P$ from Fisher's table, for each comparison.

\begin{tabular}{|c|c|c|c|c|}
\hline Length & $\begin{array}{l}\text { Mean weight } \\
\text { male }\end{array}$ & $\begin{array}{l}\text { Mean weight } \\
\text { female }\end{array}$ & & \\
\hline $\mathrm{cm}$. & g. & g. & $t$ & $p$ \\
\hline 23 & 98 & III & $2 \cdot 8147$ & $<0.01$ \\
\hline 24 & IIO & II 3 & $\mathrm{I} \cdot 2788$ & 0.20 \\
\hline 2 & I2O & I22 & $\mathrm{I} \cdot 2752$ & 0.20 \\
\hline 2 & I3I & I33 & 0.9595 & 0.35 \\
\hline 2 & r40 & 139 & O.I7I4 & \\
\hline
\end{tabular}

The table shows that the values for " $t$ " grow smaller with each centimetre increase in the length of the fish. At $23 \mathrm{~cm}$. the means may be regarded as significantly different, but not among the larger fish. The smaller females are 
therefore definitely heavier than the males of the same length, but the difference grows less with increase of length, until there ceases to be any significant difference.

This finding means that the males must have a different relation between weight and length from the females. The females start at a higher mean weight, but are overtaken by the males with increasing length. They therefore increase in weight, with length, less rapidly than the males. This is confirmed by the calculated formulae to express the relation between weight and length in the two sexes. They are as follows:

For the males $W=0.066 \mathrm{I} L^{2 \cdot 312}$.

For the females $W=\mathrm{I} \cdot \mathrm{I} 47 \mathrm{I} L^{1 \cdot 456}$.
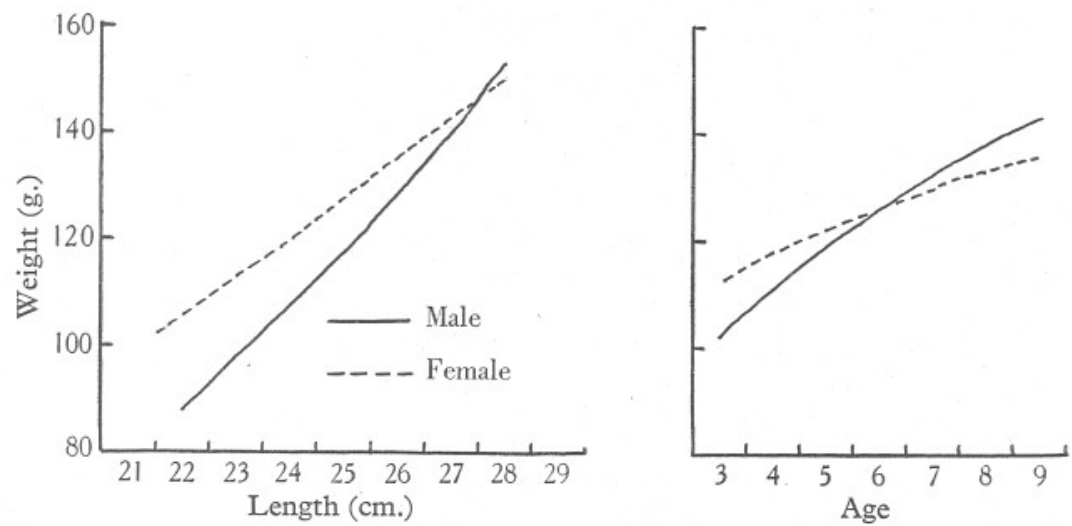

Fig. 3. Rate of increase in the weight of the gutted herring with length and age.

In Fig. 3 the mean weights of the male and female herrings at each centimetre are plotted, together with the regression lines based on the calculated mean weights (Table IV, mean weight).

In Table IV B are shown the average weights of the gutted fish at each age. Here the tendency is the same as was found in comparing length and weight, namely, the male starts at a lower mean weight, but catches up the female among the older fish.

The formulae to express the relation between age and weight are:

For the males $W=72 \cdot 5$ Age $^{0.308}$.

For the females $W=92 \cdot \mathrm{I}$ Age $^{0.177}$.

The regression lines of weight on age, together with the mean weights, are shown in Fig. 3.

\section{The Fish AND ITS Gonad}

Wynne-Edwards (I929) studied the relation between the weight of the fish and the weight of its gonad in herrings from the Isle of Man, and reached the conclusion that "spawning does not draw on the resources of the fish to a 
greater extent than can be replaced with interest, each year.... The growth of the gonads is in harmony with that of the other organs.... Death cannot be due to the increasing tax of spawning ultimately exceeding the animal's powers of recovery."

This finding cannot be said to apply to the herrings of the southern North Sea. It has been shown that, in both sexes, the weight of the gonad increases, with increase of length, at a greater rate than the weight of the body which bears it. It has been shown (p. 622) that the gonads increase in weight, with increase of length, as the 4.2 power of the length in the males, and as the 4.0 power of length in the females, whereas, it was shown (p. 627) that the weight of the fish increases, with length, as the 2.3 power of length in the males, and as the $I .5$ power of length in the females. The weight of the gonad therefore becomes an increasingly greater burden on the fish, and the ratio weight of gonad is positively correlated both with length and with age.
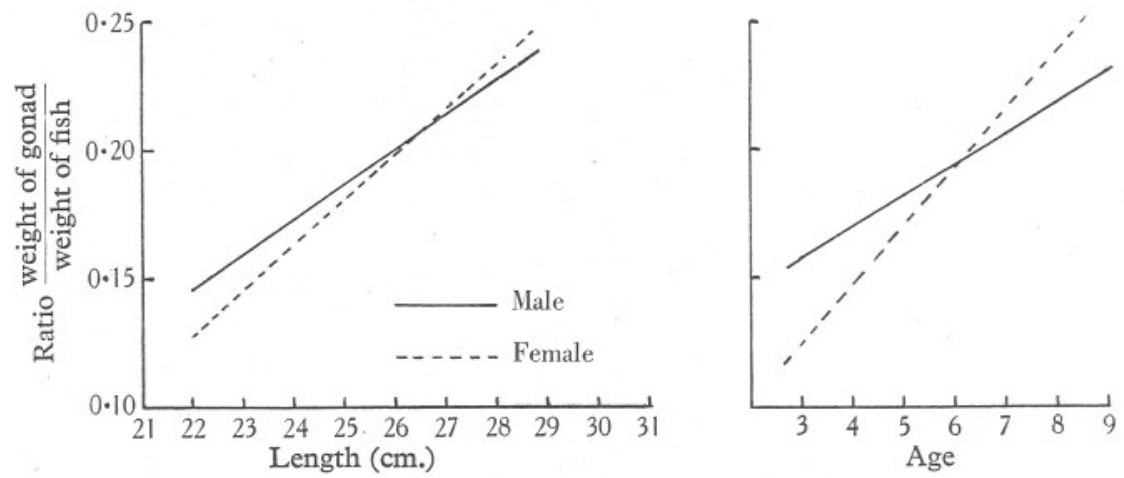

Fig. 4. Increase in the ratio $\frac{\text { weight of gonad }}{\text { weight of gutted fish }}$ with increase of length and of age in the herring.

In Fig. 4 the values of this ratio in both males and females are plotted against length and against weight. The correlation coefficients and the values for probability $P$ are as follows:

Correlation

Between length and ratio, males Between length and ratio, females Between age and ratio, males Between age and ratio, females

Coefficient
0.9432
0.9763
0.9845
0.9589

$P$

$<0$. OI

$<$ O.OI

$<$ O.OI

$<$ O.OI

The regression coefficients and formulae have been calculated from these correlation coefficients, and the regression lines are plotted in Fig. 4. The gonad represents about II \% of the weight of the fish among females of three years of age, and about 15\% among males, but the rate of increase is much greater among the females than among the males, so that at nine years 
of age the gonad represents some $27 \%$ of the weight of the fish in the female, but only some $23 \%$ in the male. If that rate of increase were maintained, the gonad would represent the absurd figure of half the weight of the fish at about twenty years of age in the female, though in the male it would then represent only some $36 \%$; and in both sexes the gonad would equal nearly half the weight of the fish at a length of about $40 \mathrm{~cm}$.

In these herrings there is a disharmony between the growth of the fish and its gonad, such that an increasing strain must be put upon the fish with increase of length and age. This strain is shown by the decrease in the condition of the fish with increase of length and age, as shown by the relation between length and weight. But the strain is obviously less in the males than in the females, and this is probably the reason why the male maintains a better rate of increase of weight, both with length and with age, than the female.

The lighter burden laid on the male must have an important effect on the rate of growth and the rate of survival. It is a common experience to find that among fishes the males grow more slowly than the females, and also die out at an earlier age and at a smaller size. This is not so with the herring. That the male does not grow at a rate different from that of the female is sufficiently shown by the fact that no worker on this fish separates the sexes when calculating the growth rate. In the matter of the better survival of the male, the herring may be contrasted with the hake. In the latter fish, as the writer has shown (Hickling, I933), the males outnumber the females among the younger fish, but the proportion of males to females progressively declines, until all fish older than twelve years are females, and only $25 \%$ of the fish from ten to twelve years of age are males. But in the hake the male becomes mature much earlier in its life than the female, and the metabolic strain is a much heavier one in the male than in the female.

In the herring there is a tendency for the proportion of males to decline, with increase of age, as was pointed out long ago by Dahl (1907), but even in his samples of Norwegian spring herrings there was still an average of some $45 \%$ of males among the fish of an age greater than twelve years. Similarly, in Collection 9 of Lea (I9IO), there were $56 \%$ of males among the ten, and 4I \% among the eleven-year old fish.

In Table IV of the present paper there are more males than females among the larger and older fish, and Dr Hodgson has very kindly put at my disposal the vast mass of data on the herring of East Anglia he has gathered. Selecting at random the years I926 and I927, and from each of these eight samples, taken both early and late in the season, the following is the average percentage of males both with regard to length and age.

\begin{tabular}{lccccccccc}
\multicolumn{8}{c}{ Length and percentage of males } \\
cm. & 21 & 22 & 23 & 24 & 25 & 26 & 27 & 28 \\
$\%$ males & 65 & 51 & 46 & 46 & 47 & 48 & 40 & 45 \\
\multicolumn{7}{c}{ Age and percentage of males } \\
Age & 3 & 4 & 5 & 6 & 7 & 8 & 9 & \\
$\%$ males & 49 & 45 & 46 & 47 & 46 & 48 & 53 &
\end{tabular}


It is clear that there is no tendency for males to become rarer among the larger and older herrings in the southern North Sea.

\section{The Comparative Spawning Powers of the Herring Shoals}

Jensen (1927) found a very good relation between the anomalies from the "normal catch" from year to year in the herring fishery at Bornholm in the Baltic, and a sine curve with a period of 3.7 years. This periodicity can be explained by the fact that the three and four-year-old fish greatly predominate in the spawning shoals, and therefore as a rule produce the largest quantity of fry. The survivors of these fry again produce large quantities of fry when they mature at three and four years of age, and so a good year class, or pair of year classes, perpetuates its abundance, and produces abundant catches at intervals of three to four years.

Dr Hodgson has given me the results of his analyses of the age composition of the East Anglian herring shoals for the years 1923 to 1938 inclusive, of which the results for the years 1923 to 1928 have already been published (Hodgson, 1929). These take the form of a percentage of fish of each age in each season. Table $\mathrm{V}$ gives the mean percentage of fish at each age for the whole series of years, together with the calculated mean number of eggs produced by the females of each age, from Table I в. Thence, by calculation, is given the comparative spawning power of each age group in the series, and finally, the percentage of the total spawning power contributed by each age group.

\section{Table V. Mean Age Composition of the East Anglian Herring Shoals, 1923-38, and Spawning Power at each Age Group}

\begin{tabular}{|c|c|c|c|c|c|c|c|}
\hline Age ... & 3 & 4 & 5 & 6 & 7 & 8 & 9 \\
\hline Mean $\%$ of fish & $\mathrm{I} 2 \cdot \mathrm{I}$ & $28 \cdot 5$ & $23 \cdot 3$ & $15 \cdot 3$ & 10.3 & $6 \cdot 0$ & 3.0 \\
\hline Mean fecundity & $\mathrm{I} 4,600$ & 17,700 & 20,500 & 23,100 & 25,600 & 27,900 & 30,200 \\
\hline $\begin{array}{l}\text { Spawning power } \\
\text { Percentage }\end{array}$ & $\begin{array}{c}\text { I76,660 } \\
8 \cdot 7\end{array}$ & $\begin{array}{c}504,450 \\
24.8\end{array}$ & $\begin{array}{c}477,650 \\
23.5\end{array}$ & $\begin{array}{c}353,430 \\
\text { I } 7 \cdot 4\end{array}$ & $\begin{array}{c}263,680 \\
13.0\end{array}$ & $\begin{array}{c}167,400 \\
8.2\end{array}$ & $\begin{array}{c}90,600 \\
4.5\end{array}$ \\
\hline
\end{tabular}

The table shows that at least three age groups contribute in a very important degree to the supply of eggs, and this would militate against the establishment of a periodicity in the abundance of eggs spawned, for a rich year class can contribute for three years in succession a supply of eggs sufficiently important to make good the deficiency due to poor year classes which precede or succeed it. It is, in fact, found that the "comparative spawning power" of these East Anglian herring shoals varies little from year to year. The ratio of the poorest to the best seasons in this series was $193: 222$, and there is no correlation between the "spawning power" of the herring shoals in any year and the percentage of three-year-old herrings which appear in the shoals three years later. 


\section{SUMMARY}

The number of eggs produced by the herrings of the East Anglian shoals increases with the length of the fish at a rate equal to the 3.465 power of the length, and with the age of the fish to the 0.66 power of the age. This fecundity is compared with that found in other races of herrings.

The number of eggs produced is closely correlated with the mean weight of the ovary, and it is found that the weight of the ovary increases with length at a rate equal to the fourth power of the length, and that a slightly higher rate applies to the testis.

The weight of the gutted fish, however, increases in relation to the length at a much slower rate, namely, as the 2.3 power of the length in the males, and the $\mathrm{I} \cdot 5$ power of the length in the females.

The gonad, therefore, represents an increasing burden on the fish with increase of length, and the same is true with regard to age. Moreover, the strain of reproduction increases more rapidly with both length and with age in the female than in the male. This fact may explain the equal growth rate of male and female herrings, and also the survival of the male herrings to reach a large size and an advanced age, both of which phenomena are contrary to those found among many species of fishes.

The mature herrings show a sharp decline in the rate of growth in weight with length, as compared with immature herrings.

The data on the fecundity of the herring are applied to the age-distribution of the herrings of the southern North Sea, and it is concluded that the known changes in the age distribution from season to season do not cause a sufficiently great variation in the "spawning power" of the shoals to account for the variations in strength of the year-classes.

\section{REFERENCES}

BJERKAN, P., I9I7. Age, maturity and quality of North Sea herrings during the years I9I0-1913. Rep. Norweg. Fish. Mar. Invest., Vol. III, No. I, II9 pp.

DAHL, K., I907. The scales of the herring as a means of determining age, growth and migration. Rep. Norweg. Fish. Mar. Invest., Vol. II, No. 6, 36 pp.

FARRAN, G. P., I938. On the size and number of the ova of Irish herrings. Fourn. Cons. Int. Explor. Mer, Vol. XIII, No. I, pp. 9I-Io0.

FISHER, R. A., I938. Statistical Methods for Research Workers. Seventh edition, $356 \mathrm{pp}$.

Fulton, T. W., I891. The comparative fecundity of sea-fishes. Ninth Ann. Rep. Fish. Board Scotland, for the Year I890, Part III, pp. 243-68.

HiCKLING, C. F., I933. The natural history of the hake. Part IV. Age-determination and the growth-rate. Min. Agric. Fish., Fish. Invest., Ser. II, Vol. xIII, No. 2, I $20 \mathrm{pp}$.

Hickling, C. F. \& RutenBeRg, E., I936. The ovary as an indicator of the spawning period in fishes. Fourn. Mar. Biol. Assoc., Vol. XxI, pp. 3II-I7.

HodGSON, W. C., I925. Investigations into the age, length and maturity of the herring of the southern North Sea. Part II. The composition of the catches in I922-I924. Min. Agric. Fish., Fish. Invest., Ser. II, Vol. vIII, No. 5, 48 pp. 
HodGsON, W. C., I929. Investigations into the age, length and maturity of the herring of the southern North Sea. Part III. The composition of the catches from I923 to I928. Min. Agric. Fish., Fish. Invest., Ser. II, Vol. XI, No. 7, 75 pp.

JENSEN, A. J. C., I927. On the influence of the quantity of spawning herrings upon the stock of the following years. Fourn. Cons. Int. Explor. Mer., Vol. II, No. I, pp. 44-9.

Keys, A. B., I928. The weight-length relation in fishes. Proc. Nat. Acad. Sci., Washington, Vol. xIV, pp. 922-5.

LEA, E., I9IO. On the methods used in the herring-investigations. Pp. 7-I74 in Hjort, Report on Herring Investigations until January I9I0. Cons. Int. Explor. Mer, Publ. Circ., No. 53, I74 pp.

Marshall, S. M., Nicholls, A. G. \& OrR, A. P., I939. On the growth and feeding of young herring in the Clyde. Fourn. Mar. Biol. Assoc., Vol. XxIII, pp. 427-55.

MitChell, A. M., I9I3. The egg-production of certain fishes. Fish. Bd. Scotland. Fifth Report (Northern Area) on Fish. \& Hydrograph. Invest. in the North Sea $\mathcal{E}$ Adjacent Waters, I908-I9II.

Nuttall, G. H. F., I9I3. Observations of the biology of the Ixodidae. Parasitology, Vol. vi, No. I.

ORTON, J. H., I9I6. An account of the researches on races of herrings carried out by the Marine Biological Association at Plymouth, I9I4-I5. Fourn. Mar. Biol. Assoc., Vol. XI, pp. 7I-I2I.

RartT, D. S., I933. The fecundity of the haddock. Fisheries, Scotland Sci. Invest., I932, No. I, 42 pp.

WYNNE-EDWARDS, V. C., I929. The reproductive organs of the herring in relation to growth. Fourn. Mar. Biol. Assoc., Vol. xvI, pp. 49-65. 